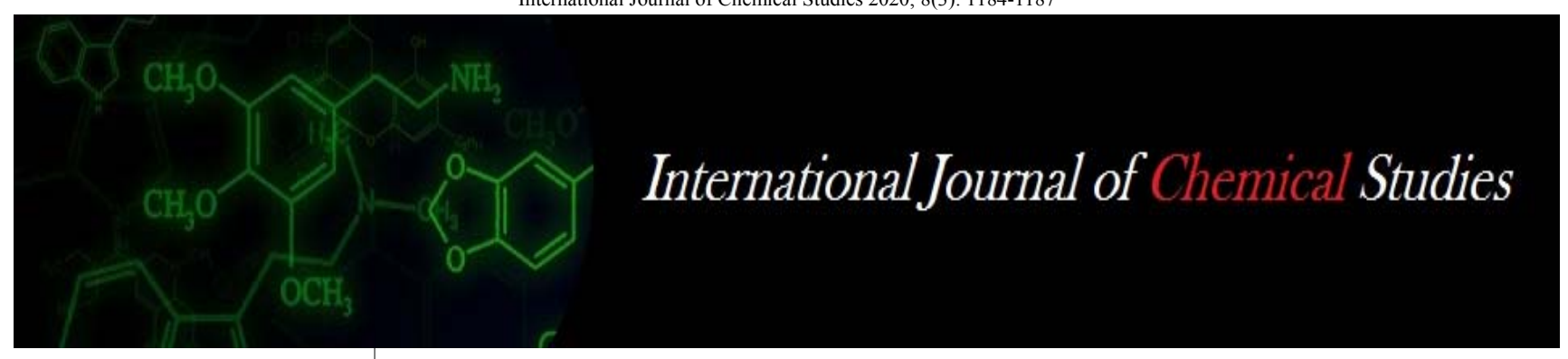

P-ISSN: 2349-8528 E-ISSN: 2321-4902 www.chemijournal.com IJCS 2020; 8(3): 1184-1187 (C) 2020 IJCS

Received: 12-03-2020 Accepted: 16-04-2020

Keertikumari Kasale Food Science and Nutrition, College of Community Science, University of Agricultural Sciences, Dharwad, Karnataka, India

Usha Malagi Professor,

Dept. Food Science and Nutrition, College of Community Science, University of Agricultural Sciences, Dharwad, Karnataka, India
Corresponding Author: Keertikumari Kasale Food Science and Nutrition, College of Community Science, University of Agricultural Sciences, Dharwad, Karnataka, India

\section{Antioxidant components of newly identified carrot germplasms}

\section{Keertikumari Kasale and Usha Malagi}

DOI: https://doi.org/10.22271/chemi.2020.v8.i3p.9362

\begin{abstract}
Nine newly identified carrot germplasms and one local carrot variety were evaluated in terms of antioxidant components and antioxidant activity. The antioxidant components of carrots viz. total carotene, beta carotene, phenols, vitamin $\mathrm{C}$ and antioxidant activity varied from $4.35-13.74 \mathrm{mg} / 100 \mathrm{~g}$, $0.91-4.16 \mathrm{mg} / 100 \mathrm{~g}, 1.97-3.98 \mathrm{mg} / 100 \mathrm{~g}, 4.01-4.7 \mathrm{mg} / 100 \mathrm{~g}$ and $24.15-32.21 \%$ respectively. Carrot germplasms UHSBC51, UHSBC53, UHSBC64 and UHSBC101 are significantly higher in total carotene and beta carotene content $(11.40-13.74 \mathrm{mg} / 100 \mathrm{~g}$ and $3.02-4.16 \mathrm{mg} / 100 \mathrm{~g}$ respectively). All carrot germplasms except UHSBC59 had significantly higher phenolic content and antioxidant activity (2.56$3.98 \mathrm{mg} / 100 \mathrm{~g}$ and $27.04-32.21 \%$ respectively) when compared with local carrot variety. There is no significant difference in vitamin $\mathrm{C}$ content of carrot germlasms. The correlation between total carotene ( $\mathrm{r}$ $=0.74)$, beta carotene $(r=0.97)$ and phenols $(r=0.91)$ were significantly and positively correlated to antioxidant activity. Germplasms UHSBC64, UHSBC101 and UHSBC44-1 were good sources of antioxidant components.
\end{abstract}

Keywords: Carrot germplasms, total carotene, beta carotene, phenol, vitamin C, antioxidant activity

\section{Introduction}

Carrot (Daucus carota L.) is one of the important root vegetables that belongs to the family Umbelliferae, genus Daucus and species carota. It is cultivated throughout the world for its fleshy edible roots and is used for human consumption. Carrot is a cool season root vegetable and it is grown in spring, summer and autumn in temperate climate and during winter in tropical and subtropical climate. Duration for maturity of carrots is 100-120 days. Different varieties of carrots are grown in Karnataka. The prominent ones are Pusa kesar, Nantes, Nantes half long, Pusa meghali, Pusa yamadagni, Arka suraj and Kuroda.

Carrot is rich in pro-healthy antioxidants. It is the only colored root crop with different types of pigments in the form of carotenoids and flavonoids that impart antioxidant properties in addition to colour. The carrot roots are the unique roots rich in carotenoids and have a characteristic flavor due to the presence of terpenoids and polyacetylenes. Carotenoid content varies considerably among carrot genotypes. Orange and red rooted carrots accumulate large amounts of carotenoids mainly $\alpha$ and $\beta$-carotene, yellow carrots contain low amounts of carotenoids and white-rooted carrots contain negligible amounts of carotenoids. Carrots are also a good source of carbohydrates and minerals like calcium, iron, phosphorous and magnesium. High biological value of carrots is mainly due to presence of carotenoid compounds.

The consumption of carrots has many health benefits. Carotenoids help for inhibition of mutagenic activity contributing to decrease the risk of cancers. Beta carotene helps to protect vision, especially night vision and provides protection against macular degeneration and development of cataract, the leading cause of blindness in aged people. Phenols exert anticarcinogenic activities, reduce inflammatory insult, and modulate immune response. Dietary fibre lowers cholesterol levels, helps to control blood sugar levels and normalize bowel movements.

High yielding newer carrot varieties are grown in the horticulture department and are not tested for their antioxidant components. Hence the present study was undertaken with an objective to analyse the antioxidant components of newly identified carrot germplasms. 


\section{Material and methods}

Nine newly identified carrot germplasms viz. UHSBC51, UHSBC52, UHSBC53, UHSBC59, UHSBC64, UHSBC101, UHSBC23-1, UHSBC34-1 and UHSBC44-1 were collected from Regional Horticulture Research and Extension centre Dharwad, University of Horticulture sciences Bagalkot, Karnatka. One variety was taken for comparison from Dharwad local market as a control (LC).

\section{Antioxidant components}

The total carotene and beta carotene were estimated by using column chromatography and absorbance of the extract was measured at $452 \mathrm{~nm}$. Polyphenol was estimated using Folin Ciocalteau reagent (Sadashivam and Manicham, 2008). Antioxidant activity was assessed using DPPH spectrophotometric method (Dorman et al., 2004) ${ }^{[4]}$. Ascorbic acid content was determined by titrimetric method by using 2, 6-dichlorophenol indophenol dye (Ranganna, 1986) ${ }^{[11]}$. The results were statistically analyzed by one way ANOVA. Correlation coefficient was used to see the correlation between the selected parameters i.e. antioxidant activity with polyphenols, carotene and beta carotene. All the statistical analysis was done using the SPSS software.

\section{Results and discussion}

The total carotene and beta carotene content of carrot germplasms are shown in the Table 1 . The total carotene and beta carotene content of carrot germplasms which ranged from $4.35-13.74 \mathrm{mg} / 100 \mathrm{~g}$ and $0.91-4.16 \mathrm{mg} / 100 \mathrm{~g}$ respectively. The differences in mean values were significant $(p<0.01)$ among the germplasms. The highest total carotene was observed in the germpalsm UHSBC64 $(13.74 \mathrm{mg} / 100 \mathrm{~g})$ and beta carotene in the germplasm UHSBC101 $(4.16 \mathrm{mg} / 100$ $\mathrm{g})$. Least level of total carotene and beta carotene was observed in the germplasm UHSBC59 $(4.35 \mathrm{mg} / 100 \mathrm{~g})$. The total carotene values of the present study are in accordance with the findings reported by Gajewski et al. (2007) ${ }^{[5]}$ and Matejkova et al. (2010) ${ }^{[8]}(0.20-14 \mathrm{~m} \mathrm{~g} / 100 \mathrm{~g})$. However Bender et al. (2009) ${ }^{[2]}$ and Bystricka et al. (2015) ${ }^{[3]}$ noted the higher values for beta carotene $(2.45-12.42 \mathrm{mg} / 100 \mathrm{~g})$. The difference in the values of total carotene and beta carotene in the present study in comparison to other studies of carrots may be due to type of cultivar, colour of carrot, maturity at harvest, temperature during growing conditions, site of production and farming practices.

The phenolic content of the carrot germplasm is presented in the Table 2. The phenolic content of the carrot germplasm ranged from $1.97-3.98 \mathrm{mg} / 100 \mathrm{~g}$. The differences in mean values were significant at $p<0.01$ level among the carrot germplasms. Highest level of phenols was observed in the germplasm UHSBC44-1 $(3.98 \mathrm{mg} / 100 \mathrm{~g})$ and least in the germplasm UHSBC59 $(1.97 \mathrm{mg} / 100 \mathrm{~g})$. The study conducted by Sharma et.al (2010) ${ }^{[13]}$ and Gajewski et al. (2010) ${ }^{[6]}$ reported lower values for phenols $(1.26-2.66 \mathrm{mg} / 100 \mathrm{~g})$. The wide variation in the values of phenolic content of the present study in comparison to other research studies of carrots may be attributed to biosynthetic pathway during plant growth and development and environmental factors including sunshine radiation, temperature variation and climatic conditions within geographical location.

The antioxidant activity of the carrot germplasm is presented in the Table 3. The antioxidant activity of the carrot germplasm ranged from $24.15-32.21 \%$ respectively. The differences in mean values were significant at $p<0.01$ level among the carrot germplasms. Highest level of antioxidant activity was observed in the germplasm UHSBC44-1 $(32.21 \%)$ and least in the germplasm UHSBC59 $(24.15 \%$ respectively). The study conducted by Bembem and Sadana (2014) ${ }^{[1]}$ and Moustafa et al. (2016) ${ }^{[9]}$ noted that different values for antioxidant activity which ranged from $7.96-$ $40.90 \%$.

Table 4 and 5 shows the correlation between total carotene, beta carotene and phenols with antioxidant activity. The total carotene $(\mathrm{r}=0.74)$, beta carotene $(\mathrm{r}=0.97)$ and phenols $(\mathrm{r}=0.91)$ were significantly and positively correlated to antioxidant activity. The correlation between different antioxidants and antioxidant activity was significant $(p<0.01 \%)$. The correlation between total carotene and antioxidant activity in the present study was 0.74 , between beta carotene and antioxidant activity was 0.97 and also between phenols and antioxidant activity was 0.91 (Table 4 and 5). These relationships show that antioxidant activity of carrots is related to total carotene, beta carotene and phenolic content. The biological effects of carotenes are independent of beta carotene activity and have been attributed to the antioxidant activity of carotenoids, through deactivation of free radicals and singlet oxygen quenching (Sharma et al. 2010) ${ }^{[13]}$. The antioxidant activity of phenolic acids and their esters depend on the number of hydroxyl groups in the molecule (Jagadish Singh 2012) ${ }^{[7]}$. The present study is in agreement with the findings of Nicolle et al. (2004) ${ }^{[10]}$ and Gajewski et al. (2007) [5] for relationship between total carotene and antioxidant activity, beta carotene and antioxidant activity and phenols and antioxidant activity for different coloured carrots. Due to the appreciable level of different antioxidants present in carrots they are considered as a functional food with significant health promoting properties.

The vitamin $\mathrm{C}$ level of the carrot germplasms are shown in Figure 1. The vitamin $\mathrm{C}$ level of carrots varied from $4.01-$ $4.7 \mathrm{mg} / 100 \mathrm{~g}$ and differences in means not significant. Highest vitamin $\mathrm{C}$ level was found in the germplasm UHSBC52 (4.7 $\mathrm{mg} / 100 \mathrm{~g})$ and least in UHSBC53 $(4.01 \mathrm{mg} / 100 \mathrm{~g})$. The values of vitamin $\mathrm{C}$ content in our study are different from the research studies reported by Nicolle et al. (2004) ${ }^{[10]}$ and Bender et al. (2007) ${ }^{[2]}$ (ranged from $1.4-$ $6.2 \mathrm{mg} / 100 \mathrm{~g}$ ) but Bembem and Sadana (2014) ${ }^{[1]}$ reported lower value for vitamin C (3.02 mg/100 g). The difference in the values of vitamin $\mathrm{C}$ of the present study in comparison to other research studies may be due to varietal difference, environmental factors namely light, temperature, salt and drought stress, atmospheric pollutants, metals or other herbicides.

\section{Conclusion}

The nine newly identified high yielding carrot germplasms were good source of antioxidant components. When carrot germplasms were compared with local carrot variety Germplasms UHSBC51, UHSBC53, UHSBC64 and UHSBC101 are significantly higher in total carotene and beta carotene content (11.40-13.74 $\mathrm{mg} / 100 \mathrm{~g}$ and 3.02-4.16 $\mathrm{mg} / 100 \mathrm{~g}$ respectively). All carrot germplasms except UHSBC59 had significantly higher phenolic content and antioxidant activity $(2.56-3.98 \mathrm{mg} / 100 \mathrm{~g}$ and $27.04-32.21 \%$ respectively) when compared with local carrot variety. There is no significant difference in vitamin $\mathrm{C}$ content of local carrot variety and newly identified carrot germplasms. In conclusion the carrot germplasms viz. UHSBC64, UHSBC101 and UHSBC44-1 were found to be best in terms of antioxidant components and antioxidant activity. 
Table 1: Total carotene and beta-carotene content of carrot germplasms

\begin{tabular}{|c|c|c|}
\hline \multirow{2}{*}{ Carrot germplasms } & \multicolumn{2}{|c|}{ Carotenoids (mg/100g) } \\
\cline { 2 - 3 } & Total carotene & Beta carotene \\
\hline LC (Control) & $9.36 \pm 0.25^{\mathrm{e}}$ & $2.50 \pm 0.16^{\mathrm{d}}$ \\
\hline UHSBC 51 & $12.47 \pm 0.26^{\mathrm{c}}$ & $3.57 \pm 0.26^{\mathrm{b}}$ \\
\hline UHSBC 52 & $8.53 \pm 0.21^{\mathrm{f}}$ & $2.34 \pm 0.30^{\mathrm{d}}$ \\
\hline UHSBC 53 & $11.40 \pm 0.32^{\mathrm{d}}$ & $3.02 \pm 0.05^{\mathrm{c}}$ \\
\hline UHSBC 59 & $4.35 \pm 0.25^{\mathrm{h}}$ & $0.91 \pm 0.05^{\mathrm{e}}$ \\
\hline UHSBC 64 & $13.74 \pm 0.19^{\mathrm{a}}$ & $4.12 \pm 0.11^{\mathrm{a}}$ \\
\hline UHSBC 101 & $13.23 \pm 0.24^{\mathrm{b}}$ & $4.16 \pm 0.22^{\mathrm{a}}$ \\
\hline UHSBC 23-1 & $9.16 \pm 0.16^{\mathrm{e}}$ & $2.50 \pm 0.16^{\mathrm{d}}$ \\
\hline UHSBC 34-1 & $8.74 \pm 0.21^{\mathrm{f}}$ & $2.19 \pm 0.16^{\mathrm{d}}$ \\
\hline UHSBC 44-1 & $8.11 \pm 0.18^{\mathrm{g}}$ & $2.28 \pm 0.11^{\mathrm{d}}$ \\
\hline Mean \pm SD & $9.51 \pm 2.82$ & $2.66 \pm 0.98$ \\
\hline F- value & 436.99 & 91.18 \\
\hline S. Em. \pm & 0.12 & 0.10 \\
\hline C. D. @ 1\% level & $0.38^{* *}$ & $0.29^{* *}$ \\
\hline
\end{tabular}

Note: Mean \pm S.D; C.D - Critical Difference; S. Em. \pm Standard Error mean; ** Significant at 0.01 percent level; Different superscript within a column indicate significant difference at 0.05 level by DMRT

Table 2. Phenolic content of carrot germplasms

\begin{tabular}{|c|c|}
\hline Carrot germplasms & Phenols (mg/100 g) \\
\hline LC (Control) & $2.38 \pm 0.05^{\mathrm{e}}$ \\
\hline UHSBC 51 & $3.58 \pm 0.09^{\mathrm{b}}$ \\
\hline UHSBC 52 & $2.68 \pm 0.04^{\mathrm{d}}$ \\
\hline UHSBC 53 & $3.35 \pm 0.07^{\mathrm{c}}$ \\
\hline UHSBC 59 & $1.97 \pm 0.04^{\mathrm{f}}$ \\
\hline UHSBC 64 & $3.66 \pm 0.08^{\mathrm{b}}$ \\
\hline UHSBC 101 & $3.90 \pm 0.07^{\mathrm{a}}$ \\
\hline UHSBC 23-1 & $2.56 \pm 0.08^{\mathrm{d}}$ \\
\hline UHSBC 34-1 & $2.66 \pm 0.06^{\mathrm{d}}$ \\
\hline UHSBC 44-1 & $3.98 \pm 0.05^{\mathrm{a}}$ \\
\hline Mean \pm SD & $3.07 \pm 0.68$ \\
\hline F- value & 205.44 \\
\hline S. Em. \pm & 0.13 \\
\hline C. D. @ 1\% level & $0.42^{* *}$ \\
\hline
\end{tabular}

Note: Mean \pm S.D; C.D - Critical Difference; S. Em. \pm Standard Error mean; ** Significant at 0.01 percent level; Different superscript within a column indicate significant difference at 0.05 level by DMRT

Table 3: Antioxidant activity of carrot germplasms

\begin{tabular}{|c|c|}
\hline Carrot germplasms & Antioxidant activity (\%) \\
\hline LC (Control) & $28.32 \pm 0.39^{\mathrm{d}}$ \\
\hline UHSBC 51 & $31.36 \pm 0.15^{\mathrm{b}}$ \\
\hline UHSBC 52 & $28.67 \pm 0.57^{\mathrm{c}}$ \\
\hline UHSBC 53 & $31.19 \pm 0.37^{\mathrm{a}}$ \\
\hline UHSBC 59 & $24.15 \pm 0.52^{\mathrm{e}}$ \\
\hline UHSBC 64 & $31.59 \pm 0.50^{\mathrm{ab}}$ \\
\hline UHSBC 101 & $31.12 \pm 0.10^{\mathrm{b}}$ \\
\hline UHSBC 23-1 & $28.96 \pm 0.38^{\mathrm{c}}$ \\
\hline UHSBC 34-1 & $27.04 \pm 0.07^{\mathrm{d}}$ \\
\hline UHSBC 44-1 & $32.21 \pm 0.30^{\mathrm{a}}$ \\
\hline Mean \pm SD & $29.41 \pm 2.66$ \\
\hline F- value & 156.27 \\
\hline S. Em. \pm & 0.21 \\
\hline C. D. @ $1 \%$ level & $0.63^{* *}$ \\
\hline
\end{tabular}

Note: Mean \pm S.D; C.D - Critical Difference; S. Em. \pm Standard Error mean; ** Significant at 0.01 percent level; Different superscript within a column indicate significant difference at 0.05 level by DMRT
Table 4: Correlation between carotene and antioxidant activity

\begin{tabular}{|c|c|c|c|}
\hline Compound & $\begin{array}{c}\text { Total } \\
\text { carotene }\end{array}$ & $\begin{array}{c}\text { Beta } \\
\text { carotene }\end{array}$ & $\begin{array}{c}\text { Antioxidant } \\
\text { activity }\end{array}$ \\
\hline Total carotene & 1 & $0.97^{* *}$ & $0.74^{* *}$ \\
\hline Beta carotene & & 1 & $0.75^{* *}$ \\
\hline $\begin{array}{c}\text { Antioxidant } \\
\text { activity }\end{array}$ & & & 1 \\
\hline
\end{tabular}

${ }^{*}$ Correlation is significant at 0.01 level.

Table 5: Correlation between phenols and antioxidant activity

\begin{tabular}{|c|c|c|}
\hline Compound & Phenols & Antioxidant activity \\
\hline Phenols & 1 & $0.91^{* *}$ \\
\hline Antioxidant activity & & 1 \\
\hline
\end{tabular}

${ }^{* *}$ Correlation is significant at 0.01 level.

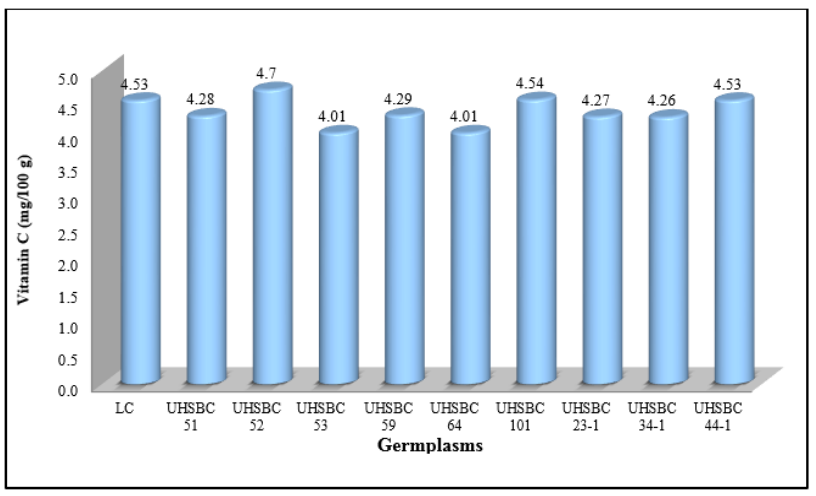

Fig 1: Vitamin C content of carrot germplasms on fresh weight basis

\section{References}

1. Bembem K, Sadana B. Effect of different cooking methods on the antioxidant components of carrot. J. Bio sci. Dicovery., 2014; 5(1):112-116.

2. Bender I, Ess M, Matt D, Moor U, Tonutare T, Luik A. Quality of organic and conventional carrots. J. Agric. Res., 2007; 7(2):572-577.

3. Bystricka J, Kavalcova P, Musilova J, Vollmannova A, Tosh T, Lenkova M. Carrot as a source of antioxidants. $J$. Acta. Agric. Solvenica, 2015; 2:303-311.

4. Dorman HJ, Bachmayer O, Kosar M, Hittumen R. Antioxidant properties of aqueous extracts from selected Lamiaceace species grown in Turkey. J. Agri. Food Chem., 2004; 52:762-770.

5. Gajewski M, Szymczak P, Elkner K, Dabrowsk A, Kret A, Danilcenko H. Some aspects of nutritive and biological value of carrot cultivlars with orange, yellow and purple coloured roots. J. Veg. Crop. Res., 2007; 67:149-161.

6. Gajewski M, Szymczak P, Danilcenko H. Changes of physical and chemical traits of roots of different carrot cultivars under cold store conditions. J.Veg. Crop. Res., 2010; 72:115-127.

7. Jagadish Singh. Bio- chemistry of vegetables. Narendra Publishing House, Delhi., 2012.

8. Matejkova J, Petrikov K. Variation in content of carotenoids and vitamin $\mathrm{C}$ in carrots. J.Notulae Scientia Biologica., 2010; 2(4):88-91.

9. Moustafa M, Hussein A, Mohammada A. Introduction of purple and deep purple carrot hybrids to Egypt showed high antioxidant activity and high content of total flavonoids and phenols. J. Basic Appl. Res., 2016; 2(22):148-156.

10. Nicolle C, Simon G, Rock E, Amouroux P, Remesy C. Genetic variability influences carotenoids, vitamin, 
phenolic and mineral content in white, yellow, purple, orange and dark orange carrot cultivars. J. American Soc. Hort. Sci., 2004; 129(4):523-529.

11. Ranganna S. Handbook of Analysis and Quality Control for Fruit and Vegetable Products, $2^{\text {nd }}$ edn., Tata McGrawHill Publishing Company Limited, New Delhi. 1986; 910:105-106.

12. Sadashivam S, Manicham A. Biochemical methods. New Age International Publishers, New Delhi, India, 2008.

13. Sharma K, Karki S, Thakur N, Attri S. Chemical composition, functional properties and processing of carrot. J. Food Sci. Technol., 2010; 49(1):22-32. 